\title{
Indigestão colonial em alguns poemas da Revista de Antropofagia
}

\author{
Rodrigo Octávio Cardoso*
}

\begin{abstract}
Resumo
Parte do projeto do modernismo brasileiro foi a afirmação de uma literatura nacional autêntica no espaço mundial da modernidade estabelecido como conjunto de Estados nacionais. Entretanto, a escrita do texto moderno foi marcada por aquilo que Denise Ferreira da Silva (2007) chama de globalidade, isto é, a atribuição de transparência ao sujeito europeu e de afetabilidade aos seus outros raciais, que ocupavam outros espaços. Essa separação se expressou como uma forma peculiar de angústia de influência em diversos textos literários modernistas que buscavam estabelecer sua autenticidade diante de uma tradição literária ocidental que, por sua vez, não os reconhecia. Neste artigo, proponho uma leitura de diferentes manifestações dessa angústia de influência e separação em alguns célebres poemas modernistas publicados originalmente na Revista de Antropofagia por Murilo Mendes, Mário de Andrade, Manuel Bandeira, Carlos Drummond de Andrade e Oswald de Andrade.

Palavras-chave: Modernismo. Globalidade. Angústia de influência. Ocidente. Poesia moderna.
\end{abstract}

Professor Assistente de Teoria Literária na UFRJ, doutor em Teoria e História Literária pela UNICAMP. https://orcid.org/ 0000-0002-7488-6532. 


\title{
Colonial indigestion in a few poems in the Revista de Antropofagia
}

\begin{abstract}
Part of the Brazilian modernist project was the affirmation of an authentic national literature in the worldwide spatiality of modernity, established as an ensemble of nation-States. However, the writing of the modern text postulated that which Denise Ferreira da Silva (2007) calls globality, that is, the attribution of transparency to the European subject and of affectability to their racial others who inhabited other spaces. This separation expressed itself as a peculiar form of anxiety of influence in many modernist literary texts which sought to establish their authenticity in face of a western literary tradition which, in turn, did not recognize them. In this article, I propose a reading of different manifestations of this anxiety of influence and separation in a few famous modernist poems originally published in the Revista de Antropofagia by Murilo Mendes, Mário de Andrade, Manuel Bandeira, Carlos Drummond de Andrade and Oswald de Andrade.
\end{abstract}

Keywords: Modernismo. Globality. Anxiety of influence. West. Modern poetry.

Recebido em: 29/09/2021 // Aceito em: 27/11/2021. 
Cem anos após a declaração de independência do Brasil, a identidade nacional e o lugar do país no concerto das nações modernas eram preocupações centrais de intelectuais e escritores brasileiros. Os anos 1920 e 1930 dão testemunho de um enorme esforço intelectual de imaginar a nação em obras que ressoam, ainda hoje, na política e na cultura brasileiras, tais como as de Manoel Bomfim, Oliveira Vianna, Paulo Prado, Gilberto Freyre e Sérgio Buarque de Holanda. Esses ideólogos desdobraram-se para interpretar e projetar o Brasil como uma nação moderna segundo os modelos universalistas e eurocêntricos que constituem esse paradigma, como a ideia romântica de cultura nacional unindo organicamente língua, povo e terra (ANDERSON, 2011; CHEAH, 2003). Entretanto, a formulação de um texto nacional moderno apresentava dificuldades particularmente angustiantes em um país marcado por um histórico colonial e pela miscigenação. Diante das teorias do racismo científico de Arthur de Gobineau, Ernst Haeckel, Paul Broca e outros, oriundas da Europa, e que agora proliferavam pelo mundo todo, bem como da ascensão dos movimentos eugenistas, ${ }^{1}$ a chamada "mancha negra" se apresentava como mais um empecilho para o desejo da elite brasileira de ser considerada moderna e ocidental.

Como mostra Denise Ferreira da Silva (2007), o texto moderno da filosofia, da história e das ciências havia se constituído sempre já a partir da globalidade e da co-figuração dos europeus e seus outros raciais, como eus-transparentes e como eus-afetáveis, respectivamente. Isto é, a modernidade associava ao espaço europeu os atributos da razão transcendental e da autodeterminação e ao resto do mundo a determinação

\footnotetext{
$1 \quad$ Em 1929 acontece o $1^{\circ}$ Congresso Brasileiro de Eugenia no Rio de Janeiro, liderado por Renato Kehl e Edgard Roquette-Pinto (este último apresenta uma voz divergente, criticando o racismo biológico), com o apoio de intelectuais destacados como Monteiro Lobato. Cf. Stepan (2015).
} 
segundo as leis da natureza que justificava sua dominação pelos sujeitos pós-iluministas. Para os Estados nacionais póscoloniais do Novo Mundo, a entrada na modernidade exigia uma negociação com a globalidade na confecção do texto nacional. Nos Estados Unidos, como argumenta Ferreira da Silva, isso significou postular uma continuidade histórica com o espaço europeu e a segregação de uma minoria racializada "afetável" em um espaço determinado e limitado da nação. No caso do Brasil, essa negociação envolveu um jogo tenso que postulava a continuidade do desejo e da subjetividade masculinas europeias sobre o território nacional e sobre os corpos das mulheres negras e indígenas a partir da figura da miscigenação, expressa primeiro na teoria do embranquecimento, no final do século XIX e início do século $\mathrm{XX}$, e sobrecodificada, posteriormente, pelo mito da "democracia racial". Em ambos os casos, o objetivo final seria a obliteração dos corpos e subjetividades racializados e a formação de uma nação branca, o que se exprime em uma série de políticas de extermínio das populações não brancas, tais como a não inclusão social da população negra após a abolição legal da escravidão, incentivos à miscigenação e à imigração de brancos europeus, restrições a imigrantes não europeus e a constante perseguição policial a negros que perdura até os dias de hoje no país. Em todo caso, diante da modernidade, a presença dos corpos racializados no espaço e na cultura nacionais permanece como uma "ameaça" à transparência do sujeito nacional, mesmo em autores que a princípio rejeitavam o projeto explicitamente racista do embranquecimento. Nesses casos, como revelam diversos textos da Revista de Antropofagia, publicada em São Paulo entre 1928 e 1929, o projeto modernista de fundar uma literatura autenticamente nacional é marcado por uma angústia 
colonial, ou uma certa indigestão, em sua tentativa de incorporar expressões da língua, da cultura e das subjetividades atravessadas pela presença de um povo racializado e que carregam os traços da separação postulada pela globalidade.

Após um primeiro momento de busca por novas formas de expressão, modernas e cosmopolitas, as preocupações do modernismo paulista passam a girar em torno do caráter nacional da cultura brasileira e da significação da cultura popular, como demonstra Eduardo Jardim de Moraes (1988). É o que expressa, por exemplo, a frase do Manifesto da Poesia Pau-Brasil de Oswald de Andrade, publicado em 1924: “Os casebres de açafrão e de ocre nos verdes da favela, sob o azul cabralino, são fatos estéticos [...]" (ANDRADE, 2011, p. 49). Inserida em um processo global de modernização, que, como afirma Harry Harootunian (2010), significa também a produção da história como história nacional, a poesia pau-brasil de Oswald de Andrade reivindica o local como material poético. Além disso, reivindica que essa poesia tenha seu lugar reconhecido nos fluxos internacionais de circulação de bens culturais. "Dividamos: Poesia de importação. E a Poesia Pau Brasil, de exportação.” (ANDRADE, 2011, p. 61).

Em resposta às propostas de Oswald de Andrade, o Grupo Verdeamarelo adota, nos anos seguintes, uma posição antagônica à do autor, rejeitando suas influências francesas imediatas como modismos e sustentando um nacionalismo estrito e xenófobo em uma série de textos publicados nas páginas do Correio Paulistano, jornal ligado ao Partido Republicano Paulista, que hegemonizava a política nacional. ${ }^{2}$ Em três artigos com o mesmo título, "Matemos Pery", publicados em 1921, 1925 e 1927, Menotti Del Picchia (1927) ataca as tentativas

2 Para uma excelente análise das publicações dos Verdeamarelos, cf. Queiroz (2010). 
do romantismo brasileiro de fundar sobre a figura do "índio" a identidade brasileira e defende o caráter e as origens latinas da cultura nacional, reivindicando a loba romana como seu totem. A afirmação de Del Picchia gera uma série de respostas e propostas alternativas e o grupo finalmente se reorganiza, um Del Picchia vencido incluso, em torno de Plínio Salgado e de sua proposta de elevar a anta à posição de totem nacional. Segundo o "Manifesto Nheengaçu Verde-Amarelo" (O ATUAL, 1927), a identidade do brasileiro teria surgido na expulsão dos selvagens tapuias pelos tupi, que teriam então se convertido radicalmente ao cristianismo e à cultura ocidental. $\mathrm{O}$ suposto temperamento dócil e cordial dos tupi levaria, assim, à absorção harmônica dos traços portugueses e africanos formando enfim o brasileiro. Essa fusão estaria epitomizada na figura do bandeirante, representante máximo do empreendedorismo paulista e do caráter heroico da figura nacional. Dessa forma, a manobra do Grupo da Anta propõe a conciliação do caráter miscigenado da população brasileira com uma adesão completa e irrestrita aos valores tradicionais e conservadores da civilização ocidental.

Em parte como resposta ao arielismo ${ }^{3}$ e ao lusitanismo cultural e religioso dos conservadores do Grupo da Anta, publicase, em 1928 e 1929, em São Paulo, a Revista de Antropofagia. Liderados por Oswald de Andrade, os antropófagos buscarão uma formulação alternativa para o problema da cultura nacional, sua relação com a cultura popular e com os influxos culturais europeus. Como sugerem Antonio Candido (1987b) e Heloísa Toller Gomes (2011), a escassa menção a negros e elementos afro-brasileiros na Revista de Antropofagia demonstra um desconcerto diante da forte presença desse contingente na

\footnotetext{
3 Em Ariel (1900) o uruguaio José Enrique Rodó mobiliza os personagens de A tempestade, de Shakespeare, e propõe que a América Latina deveria recusar o "calibanismo" materialista norte-americano e buscar uma nova cultura espiritual inspirada em Ariel e fundada na Antiguidade Clássica, ideia que se tornou lugar comum em muitos países da região no início do século XX. A esse respeito ver Jáuregui (2008).
} 
população brasileira e a dificuldade das elites brancas, apontada por Abdias Nascimento (2016), de lidar com a chamada "mancha negra". Por outro lado, a representação do indígena como fundamento mítico da cultura brasileira sem, entretanto, qualquer menção de povos indígenas contemporâneos, não se descola totalmente da estratégia verdeamarela de apresentar uma diferença e autenticidade em relação ao discurso eugenista arianista europeu, atribuindo valor de autenticidade e diferença para o caráter miscigenado brasileiro. Essa estratégia, ao mesmo tempo que minimiza a importância do negro, confina o indígena ao passado da cultura nacional moderna sob a hegemonia branca. ${ }^{4}$

Entretanto, ao contrário da abordagem ao mesmo tempo xenófoba com relação aos influxos culturais contemporâneos e lusófila com relação à língua e cultura herdada dos colonizadores, defendida pelos verdeamarelos, os colaboradores da Revista de Antropofagia - particularmente Oswald de Andrade - teorizam uma dinâmica cultural complexa de apropriação criativa e seletiva, simbolizada pela antropofagia, e rejeitam o legado tradicionalista e conservador da colonização, associado ao cristianismo e ao eurocentrismo. O tupinambá antropófogo précabralino é proposto como símbolo e ideal de autonomia moral, criatividade, liberdade sexual e capacidade de incorporação crítica e interessada de elementos culturais estrangeiros.

Imersa nas questões de sua época, por meio de um conjunto amplo e diverso de breves ensaios e narrativas, poemas, citações, ilustrações, crônicas e manifestos, a Revista de Antropofagia buscava dar corpo aos debates e aos desenvolvimentos da produção modernista sete anos após as promessas da Semana de Arte Moderna de 1922. Entre um grande número de poemas provincianos sobre a vida bucólica nas cidades do interior, um

4 Desenvolvo mais extensamente o argumento de que antropofagia faz parte da estratégia da branquitude brasileira de hegemonização do legado miscigenado da colonização em Cardoso (2018) e em Cardoso (2021). 
ou outro poema em que se retrata o acelerado desenvolvimento urbano e a migração na capital paulista, além de diversos textos com temas folclóricos, há alguns poemas publicados em suas páginas que se tornariam centrais para o cânone modernista como No meio do caminho, de Carlos Drummond de Andrade; Canção do Exílio, de Murilo Mendes; Noturno da Rua da Lapa, de Manuel Bandeira, e Lundu do Escritor Difícil, de Mário de Andrade. Publicados mais tarde em antologias autorais dos grandes nomes do modernismo, foram interpretados quase sempre no âmbito da obra de seus autores, sem muita atenção para sua publicação inédita e original no contexto da revista. Tendo isso em vista, proponho, a seguir, uma leitura de alguns desses poemas em seu contexto de publicação original, tendo em vista, principalmente, as tentativas de elaboração da cultura brasileira em sua relação tensa e, muitas vezes, angustiante, com a tradição cultural eurocentrada ou ocidental.

No sétimo número da Revista, em seu primeiro ano, encontramos o poema República, de Murilo Mendes:

Republica

Deodoro todo nos trinques

bate na porta do Dão Pedro $2^{\circ}$.

Seu Imperadô, dê o fóra

que nós queremos tomar conta desta bugiganga.

Mande vir os muzicos.

O imperador camarada responde

Pois não meus filhos não se vexem

me deixem calçar as chinelas

pódem entrar á vontade.

Só peço que não me bulam nas obras completas de Vitor Hugo.

(RIO DE JANEIRO)

Murilo Mendes

(Revista de Antropofagia, I-7, p.1). ${ }^{5}$

5 Nas citações da Revista de Antropofagia, mantenho a grafia original da publicação. 
Em República, o imperador D. Pedro $2^{\circ}$ dá as boas-vindas ao golpe que vai dar fim ao Império Brasileiro. A Proclamação da República é um marco oficial e definitivo de uma ruptura do Estado brasileiro com sua linhagem portuguesa. Mas, aqui, Murilo Mendes aponta para a artificialidade simbólica desse marco histórico de ruptura. No poema, a cena da ruptura é mediada pela cordialidade de um acordo tácito no interior de uma elite que compartilha dos mesmos valores. Fidalgo, filho de um rei português, bem aclimatado ao Brasil, calçando suas chinelas, o imperador do poema não fica indignado e não se abala com a entrada do velho companheiro militar nem a repele como uma traição. A transição se dá tranquilamente sobre o fundamento e sob a condição de uma continuidade discursiva designada pelas "obras completas de Vitor Hugo". Curiosamente, a Primeira República não deveria retomar os clássicos portugueses, menos ainda basear-se em tradições locais: a constituição da transição é o liberalismo romântico da obra de Victor Hugo. O acordo liberal entre o monarca escravocrata e o ditador militar certamente parece ser fruto de uma ideia fora do lugar, segundo a noção de Roberto Schwarz (2009a). O olhar irônico do poeta atenta, de modo particular, para a afinidade prioritária da elite governante e de sua cultura oficial com a tradição cultural centro-europeia, que, por sua vez, proclamava ideias liberais e humanistas no auge de sua expansão imperialista e dominação colonial. De todo modo, o poema coloca em jogo a artificialidade da ruptura, seja com os laços umbilicais europeus da elite governante, seja com a mentalidade monárquica na república.

Essa artificialidade também é descrita por Roberto Schwarz em Nacional por subtração. Nesse ensaio, o crítico descreve o fatídico mal-estar do intelectual brasileiro com "a experiência 
do caráter postiço, inautêntico, imitado da vida cultural que levamos [...]" (SCHWARZ, 2009b, p. 109). Um dos exemplos usados por Schwarz para esse mal-estar da cultura emprestada é o poema Lundu do escritor difícil, de Mário de Andrade, publicado originalmente no n. 7 do Ano I da Revista, em que o poeta "chamava de macaco o compatriota que só sabia das coisas do estrangeiro [...]" (SCHWARZ, 2009b, p. 110). Aqui, a questão da artificialidade se desloca do âmbito ideológicopolítico para o âmbito linguístico-poético:

Lundu do escritor difícil

Eu sou um escritor difícil

Que a muita gente enquisila

Porêm essa culpa é fácil

De acabar duma vez:

É só tirar a cortina

Que entra luz nesta escurez.

Cortina de brim caipora

Com teia caranguejeira

E enfeite ruim de caipira.

Fale fala brasileira

Que você enxerga bonito

Tanta luz nessa capoeira

Tal-e-qual numa gupiara.

Misturo tudo num saco

Mas gaúcho maranhense

Que para no Mato Grosso

Bate este angú de caroço

Ver sopa de carurú;

A vida é mesmo um buraco;

Bobo é quem não é tatú!

Eu sou um escritor difícil

Porêm culpa de quem é!

Todo difícil é fácil

Abasta a gente saber. 
Bagé piché chué, ôh "xavié",

De tão fácil virou fossil,

O difícil é aprender!

Virtude de urubutinga

De enxergar tudo tão longe!

Não carece vestir tanga

Pra penetrar meu cassange!

Você sabe o francês "singe"

Mas não sabe o que é guariba?

Pois é macaco, seu mano,

Que só sabe o que é da estranja.

Mario de Andrade

(Revista de Antropofagia, I-7, p. 3)

Além da crítica final à macaqueação dos manos, Mario de Andrade contrapõe a adoção de termos em língua estrangeira ("o francês 'singe") com uma aglomeração de termos regionais e populares, muitos de origem indígena ou africana, compondo, em seu conjunto, uma espécie de crioulo brasileiro geral. Dessa forma, busca suplantar a cultura e a linguagem emprestados por uma língua que se harmonizaria melhor com a experiência da vida nacional. Como se no ritmo mesmo da vida se pudesse procurar uma forma de enxergar, de escrever e fazer corresponder as palavras, sons e signos a uma imagem orgânica da nação. $\mathrm{O}$ poeta modernista responde à acusação de ter uma escrita difícil afirmando-a como popular e local, defendendo o conhecimento e o uso dos costumes, vocabulários, imagens e ritmos das populações e do território brasileiro, contra a macaqueação do que é estrangeiro. 
No poema de Mario, a própria cortina que ofusca a visão sobre o nacional é feita desses elementos da terra - "Cortina de brim de caipora/Com teia caranguejeira/E enfeite ruim de caipira" -, sugerindo a inescapabilidade da crioulização descrita por Glissant (2005), a criação de uma novidade imprevisível a partir de rastros da memória de culturas que sobreviveram à violência do encontro colonial. Nesse caso, a própria cortina ideológica que visa ocultar a realidade da terra e desviar o olhar para as metrópoles culturais é feita de elementos autóctones que revelam inevitavelmente o que se buscava ocultar.

Ao mesmo tempo, o nacional é compreendido como composição eclética de dizeres e costumes que o poeta mistura "tudo num saco/Mas gaúcho maranhense/Que para no Mato Grosso/Bate este angu de caroço [...]". Assim, no poema, não se trata de uma crítica da imitação em si, mas de uma defesa da imitação do nacional. Mario de Andrade não é um intelectual orgânico, nem essas variedades linguísticas pertencem a uma comunidade regional particular, mas constituem uma bricolagem de diversos falares populares reunidos com base em um trabalho de pesquisa etnológica. A dificuldade em ler o nacional que o poema denuncia consiste na falta de representação desse nacional para o público da elite intelectual, portador de uma visão de mundo formada com os olhos na Europa. O poeta deve se apropriar do material nacional heterogêneo e convertê-lo em forma, de modo a converter em linguagem uma experiência autêntica e popular da nação, tornando-se, assim, um legítimo representante da sociedade nacional. Nesse sentido, o poema recomenda o conhecimento dos falares brasileiros para se obter acesso a essa poesia que busca estabelecer uma mediação entre o campo da experimentação estética da elite intelectual 
e as diversas expressões vernaculares do povo. Existiria a necessidade, portanto, de adequar as representações, o jogo da fala, superando a representação disjuntiva de uma elite branca identificada com a Europa e de uma população miscigenada marcada por um suposto primitivismo indígena e africano. ${ }^{6} \mathrm{Se}$ bem-sucedido, o projeto de Mário de Andrade estabeleceria um campo comum para o mútuo reconhecimento entre o povo e a elite numa mesma comunidade linguística nacional.

Entretanto, como afirma Roberto Schwarz:

[...] a destruição programática da noção de cópia tampouco faz desaparecer o problema. Idem para a inocência programática com que o antropófago ignora o constrangimento, o qual teima em reaparecer. "Tupi or not Tupi, that is the question", na famosa fórmula de Oswald, cujo teor de contradição - a busca da identidade nacional passando pela língua inglesa, por uma citação clássica e um trocadilho - diz muito sobre o impasse. (SCHWARZ, 2009b, p. 123).

Dessa forma, o crítico vincula a crítica da imitação de Mário de Andrade ao projeto antropófago de Oswald de Andrade como formas de lidar com a sensação incômoda de dependência cultural. A inocência programática que Schwarz encontra na célebre frase de abertura do Manifesto Antropófago tem uma dupla significação. Por um lado, busca elaborar a "impureza racial brasileira", nos termos eugenistas da época, por uma relação ambígua com uma herança difusa - implicitamente biológica e cultural - indígena, que é capaz, apesar disso, ou por isso mesmo, de afirmar-se numa relação de diálogo crítico com os influxos culturais das novas metrópoles neoimperiais. Por outro lado, essa dupla injunção busca elaborar a ficção de um

6 Essa suposição é diagnosticada e reproduzida por Antonio Candido em Literatura e cultura de 1900 a 1945 (CANDIDO, 2011). A esse respeito, ver também Cardoso (2020). 
reconhecimento mútuo entre a tradição ocidental eurocentrada e a nação pós-colonial mestiça: "Sem nós a Europa não teria siquer a sua pobre declaração dos direitos do homem [...]" (Revista de Antropofagia, Ano 1, p. 3, Manifesto Antropófago). Uma ficção que só poderia soar como inocência para um teórico marxista da dependência como Schwarz.

De todo modo, o território nacional não pode ser purificado de elementos estrangeiros, como queria o poema de Mário. Além da hegemonia dos elementos culturais legados pela colonização portuguesa, o país moderno, integrado ao capitalismo global, está também povoado por lógicas, técnicas e mercadorias estrangeiras, para além da cultura francesa, que faz sucesso entre as elites. Assim, já no número 14 da segunda "dentição", Murilo Mendes procura atualizar a experiência literária canônica do exílio nessa nova realidade do processo de globalização:

Canção do Exílio

Minha terra tem macieiras da California onde cantam gaturamos de Versailles os poetas da minha terra são pretos que vivem em torres de ametista os sargentos do Exercito são monistas cubistas os filozofos são polacos vendendo a prestação a gente não póde dormir com os oradores e os pernilongos os sururus em familia têm por testemunha a Gioconda eu morro sufocado em terra estrangeira nossas flôres são mais bonitas nossas frutas mais gostosas mas custam cem mil réis a dúzia ai quem me déra xupar uma carambola de verdade ouvir um sabiá com certidão de idade!

Rio, 1924 
Murilo Mendes

(Revista de Antropofagia, II-14).

Em sua releitura do poema homônimo de Gonçalves Dias, Murilo Mendes compartilha de um desejo das coisas da terra, particularmente seus produtos naturais e sua língua: "quem me déra xupar uma carambola de verdade". Num tópos tradicional, identifica na fauna e na flora os elementos nacionais de maior valor, mas, já aí, eles aparecem de certa forma conciliados com as presenças culturais estrangeiras nos "sargentos monistas cubistas", com as "macieiras da Califórnia" e os "filósofos polacos vendendo a prestação". É curiosa também a presença dos "gaturamos", pássaros nativos da América do Sul, entretanto já modificados e importados, após terem sido inicialmente levados para compor os jardins imperiais franceses. No espírito da crítica antropofágica, o poema ridiculariza o bacharelismo da oratória oficial, comparando-a ao incômodo dos pernilongos. E se mesmo a contemplação dos moluscos ("sururus") comidos pelo povo é marcada pela presença da cultura italiana clássica representada pela Gioconda, o cenário complexo e contraditório, marcado pela cultura popular local tanto quanto por elementos estrangeiros é o ambiente no qual o poeta se sente em casa, fora de onde ele sufoca.

Como Mario, Murilo Mendes critica o distanciamento dos poetas em relação à realidade popular em suas "torres de ametista". Entretanto, a apresentação destes como "pretos" ensaia um gesto de apaziguamento com a diferença racial que marca a constituição da identidade nacional. Dessa forma, o poema sinaliza um movimento de reconhecimento da importância do elemento negro na constituição do país que, de fato, já encontra mais lugar na chamada segunda "dentição" da revista - as 
edições publicadas no Diário de São Paulo em 1929, com um grupo mais restrito de colaboradores e um tom mais radical. Um reconhecimento praticamente ausente no primeiro ano da publicação, senão por um ou outro texto etnológico de Mario de Andrade e Câmara Cascudo, sempre marcados pelo índice exotizante e redutor de "folclore".

Se Canção do Exílio fala da saudade da terra natal, mesmo transformada pela globalização, A voz triste da terra (Ano 1, n. 5, p. 6), de Peryllo Dolivera, fala da nostalgia de uma terra inocente, intocada pelo estrangeiro, que é deixada em uma situação de irreversível melancolia após a ingenuidade local ter contato com "as coisas bonitas que os barcos trouxeram de longe". Estar em casa, portanto, tampouco significa estar pacificado e tranquilo. Se a casa marca o lugar da herança, do próprio e do familiar, aqui ela também carrega a marca inquietante e indelével do estrangeiro. Desde o exílio o olhar para o país natal torna graciosas as dissonâncias e tensões, mas, para quem fica, a vida nacional ainda é assombrada por uma herança cuja propriedade parece estar a todo momento em questão e pelos signos incômodos e proliferantes que marcam a ausência da experiência da civilização metropolitana.

Fica claro que um dos principais problemas para o discurso modernista no fim dos anos 1920 era a elaboração de uma forma de relação com a cultura europeia que permitiria à poesia e à cultura brasileira adquirirem autonomia e força própria. Para isso, era necessário, por um lado, afirmar um caráter nacional geral, capaz de conciliar a ampla miscigenação com a aspiração das elites à branquitude e, por outro lado, afirmá-la em contraposição e diálogo com a tradição ocidental. A antropofagia lidou com a primeira questão por meio da subsunção parcial das 
identidades brasileiras a um elemento indígena embranquecido, mas foi pouco capaz, entretanto, de lidar com o elemento negro, predominante, frequentemente silenciando a seu respeito. Com relação ao segundo problema, a proposta intrépida e criativa de uma identidade fundada na incorporação da alteridade deixa, como resto incômodo, o eco de um silêncio onde se esperava o tão desejado reconhecimento.

Como argumenta Alfredo César Melo, o autorreconhecimento do intelectual brasileiro, letrado na tradição ocidental, tem-se condicionado ao seu reconhecimento pelos portadores da autoridade autoconferida dessa tradição os intelectuais e literatos das nações imperialistas. Conforme o autor, se estabelece aí a "tensão de um ator (o intelectual brasileiro) que se imagina pertencente a uma comunidade (a cultura ocidental), cujos principais atores (os sistemas intelectuais dos países centrais) o ignoram solenemente." (MELO, 2016, p. 48). O Ocidente, por sua vez, que se define, entre outras coisas, pelos valores universalistas do Iluminismo europeu como a democracia, a livre circulação de ideias, o diálogo racional e a universalização da sensibilidade, na prática se reproduz segundo a lógica de uma geografia variante, hierarquizada segundo as classificações temporais da modernidade capitalista e racialmente marcada. Como demonstra Naoki Sakai (2020), no início do século XX um intelectual japonês se considerava definitivamente mais ocidental que um cidadão indiano, ou mesmo um camponês japonês. Ainda hoje, não é difícil perceber que um australiano branco e anglófono é, em geral, mais facilmente reconhecido como um ocidental que um cidadão latino-americano. Como índice discursivo, o Ocidente deixa de ser localização geográfica e passa a ser um critério de 
hierarquização e exclusão cultural com contornos distintamente racistas e imperialistas, dentro do contexto do capitalismo global, proscrevendo de seu espaço de diálogo a todos aqueles que define como "Outros".

A contradição entre o desejo implícito de ser reconhecido por essa tradição formativa e a afirmação de sua autonomia também está presente na poesia antropófaga. No quinto número do primeiro ano da Revista de Antropofagia, encontramos o Noturno da Rua da Lapa, de Manuel Bandeira:

Noturno da Rua da Lapa

A janela estava aberta. Para o quê, não sei, porém o que entrava era o vento dos lupanares, de mistura com o eco que se partia nas curvas cicloidais, e fragmentos do hino da bandeira.

Não posso atinar no que fazia: se meditava, se morria de espanto, ou se vinha de muito longe.

Nesse momento (oh! porquê precisamente nesse momento?) é que penetrou no quarto o bicho que voava, o articulado implacável, implacável!

Compreendi desde logo não haver possibilidade alguma de evasão. Nascer de novo também não adeantava! - A bomba de flit! Pensei comigo. É um insecto.

Quando o jacto fumigatório partiu, nada mudou em mim, os sinos da redenção continuaram em silencio, nenhuma porta se abriu, nem fechou. Mas o monstruoso animal FICOU MAIOR. Senti que êle não morreria nunca mais, nem sairia, comquanto não houvesse no aposento nenhum busto de Palas, nem na minh'alma, o que é pior, a recordação persistente de alguma extinta Lenora.

Manuel Bandeira

(Revista de Antropofagia, I-5, p. 1).

De um apartamento na Lapa, entre a boemia do bairro carioca e a elegância provinciana do Passeio Público, não muito 
distante dos edifícios oficiais do governo no Catete, o eu lírico percebe o vento das casas de divertimentos ("lupanares") e "fragmentos do hino da bandeira". A presença contrastante dos elementos torna as recordações opacas, colocando em questão até mesmo a pertença àquele lugar: teria o eu lírico, na verdade, vindo de muito longe? Em meio a esse torpor, o cômodo é invadido por uma presença que causa alerta e confusão.

Noturno da Rua da Lapa faz clara referência a "O Corvo", de Edgar Allan Poe. No poema do norte-americano, estando o eu-lírico sonolento "ao pé de muita lauda antiga", uma presença sombria aparece e lhe perturba a noite. Um corvo pousa sobre um busto de Atena, a deusa grega da civilização e da sabedoria, que o eu-lírico possuía em seu quarto, e, repetindo um crocitar que lhe parece a palavra nevermore (nunca mais), produz tristes recordações sobre "Lenora", sua falecida amada, a quem nunca mais verá. De tom melancólico e nostálgico, o poema romântico logo alcançou renome mundial, sendo traduzido por grandes autores como Baudelaire, Mallarmé, Machado de Assis e Fernando Pessoa. Trata da angústia do poeta diante da finitude, mas também diante da influência exercida pela tradição. Lenora representa a musa inspiradora perdida, mas sua recordação vem assombrar o poeta justo quando sua atenção parece se dissolver "ao pé de muita lauda antiga/ de uma velha doutrina agora morta.".

O poema de Bandeira retoma de forma cômica e irônica o poema de Poe. Agora, o quarto é invadido por um bicho articulado "implacável", que remete, na transposição do cenário, ao incômodo da reflexão sobre a distância da poesia ocidental experienciado naquele ambiente. $\mathrm{O}$ som do hino da bandeira, o vento dos lupanares. "Nascer de novo não adiantava". Desde 
o entrelugar do escritor latino-americano (SANTIAGO, 2000), não havia outra solução. $O$ espectro não poderia ser apaziguado enquanto não fossem feitas as vênias à civilização de empréstimo - enquanto não houvesse no aposento nenhum busto de Palas. Mais que isso, não bastavam os sinais externos, o poeta precisaria ter tido a experiência da musa ocidental. Guardar sua recordação em seu íntimo, como traço de seu caráter: "o que é pior, a recordação persistente de alguma extinta Lenora.”.

Em A angústia da influência, Harold Bloom procura estabelecer uma teoria para a crítica de poesia fundamentada em uma leitura hermenêutica da tradição e na tensa relação de repetição e distinção entre poemas e na maturação poética de autores a partir de seu embate com a obra dos precursores. Escrito já quando sua a carreira estava consolidada, o crítico não perde as oportunidades de atacar virulentamente as teorias pós-coloniais, antirracistas, marxistas e feministas, contra as quais se ressente por suas tentativas de desconstrução e reconfiguração do cânone ocidental, que defende ferrenhamente. Sintomaticamente, chama a essas críticas de "escola do ressentimento". Não obstante a mesquinhez dessa recusa ao diálogo, a teoria da influência poética de Bloom traz possibilidades interessantes para a crítica literária e pode ser apropriada em uma leitura pós-colonial da angústia da influência nos poemas da Revista de Antropofagia.

Nesse sentido, a antropofagia pode ser entendida como um projeto de elaboração coletiva da influência ocidental como legado da colonização. Conforme descreve Denise Ferreira da Silva (2007), a globalidade que caracteriza o texto moderno co-figura os europeus e seus outros raciais respectivamente como sujeitos transcendentais e corpos afetáveis, inscrevendo na separação espacial as estratégias da racialidade. A exigência 
moderna da produção poética em diálogo com a tradição literária "ocidental”, ou europeia, caracterizava a situação singular do grupo que publicava na revista, que buscava lidar com a presença e a sombra dessa tradição no texto nacional. Desse modo, essa elite intelectual eurocentrada buscava elaborar uma forma autêntica de relação com o povo e a nação que, por sua vez, aparecia sempre ameaçada de exclusão da subjetividade moderna pela presença dos outros raciais da Europa e da mestiçagem.

Em vez de um poeta individual que busca medir forças com um predecessor, observamos toda uma geração que precisa lidar não apenas com seus predecessores, nacionais ou estrangeiros, mas com o fato de que sua posição no mundo não é reconhecida por essa tradição com que busca dialogar. Em termos de uma angústia da influência, trata-se de uma situação distinta daquela vivida, por exemplo, pela chamada terceira geração modernista. Quando, décadas mais tarde, João Cabral de Melo Neto precisou lidar com a influência de Drummond (STERZI, 2011), ele podia imaginar-se, em seu revisionismo da poesia drummondiana, sendo reconhecido pelo próprio Drummond ou pelo menos pelos leitores e críticos de Drummond, e até superando-o, dentro da própria tradição já consolidada da poesia moderna brasileira em que ambos se encontravam. No caso de uma tradição literária brasileira que o modernismo, ainda nos anos 1920, busca fundar, revisando seu próprio passado romântico e parnasiano e repensando suas relações de dependência com a cultura europeia contemporânea e pregressa da qual se percebe dependente, a reciprocidade do reconhecimento ou da superação é negada e barrada, já de partida, pelo eurocentrismo do discurso da crítica e da cultura hegemônica, bem como pelo provincianismo europeu. Se essa tensão é bastante evidente em Noturno da 
Rua da Lapa, essas considerações podem, talvez, sugerir uma interpretação particular, entre as inúmeras possíveis, para o célebre e polissêmico poema de Carlos Drummond de Andrade, publicado pela primeira vez no terceiro número da Revista de Antropofagia:

No meio do caminho

No meio do caminho tinha uma pedra tinha uma pedra no meio do caminho no meio do caminho tinha uma pedra

Nunca me esquecerei desse acontecimento na vida de minhas retinas tão fatigadas.

Nunca me esquecerei que no meio do caminho tinha uma pedra tinha uma pedra no meio do caminho no meio do caminho tinha uma pedra.

(BELO-HORIZONTE)

Carlos Drummond de Andrade (Revista de Antropofagia, I-3, p. 1).

Uma "pedra no caminho" poderia ser também a barreira que se interpõe à elaboração poética. O poeta brasileiro quer fazer a grande literatura, de acordo com seu entendimento da tradição literária ocidental. Há, entretanto, um obstáculo. Ainda que produza um grande poema, poderia ele fazer parte dessa tradição? Ele poderia ser lido como uma obra autêntica e forte do que se entendia como a literatura "universal" tendo sido produzido em suas margens quase ignoradas? Dizer que havia "uma pedra no meio do caminho"é atestar também esse obstáculo concreto. Mesmo que o modernismo viesse a reconhecer em si a maturação de uma tradição poética e um ponto forte da literatura brasileira, o poema de Drummond antecipava, já, que as retinas 
dessa tradição, ainda que fatigadas, não chegariam a se esquecer do fato, ainda que o viessem a contornar. E tão concreto era o obstáculo que, duas décadas e meia mais tarde, ainda se pôde escrever, na obra mais canônica da crítica literária brasileira do século XX, que essa tradição particular não passa de "um galho secundário da portuguesa, por sua vez arbusto de segunda ordem no jardim das musas [...]" (CANDIDO, 2013, p. 11). O fato cultural, geopolítico, econômico e racial da globalidade permanecia um obstáculo imóvel no caminho, e uma questão que não cessa de se colocar.

Para Bloom, a angústia na poesia moderna resulta da distância que separa o sujeito do objeto, e o dualismo daí decorrente, entre o poeta e a poesia, a partir da distinção cartesiana entre extensão e intensidade, espaço e espírito. Para percorrer a distância até o poema, o poeta precisa lidar com o bloqueio criativo causado pela presença espectral do precursor na imagem ideal que faz do poema. "A influência poética quando envolve dois poetas fortes, autênticos - sempre se dá por uma leitura distorcida do poeta anterior, um ato de correção criativa que é na verdade e necessariamente uma interpretação distorcida [...]" (BLOOM, 2002, p. 80). No caso da constituição de uma tradição poética moderna situada além das margens do "jardim das musas", na periferia do capitalismo internacional, a situação parece se complicar. Aí o discurso eurocêntrico da tradição não reconhece nenhum sujeito. A América tropical e mestiça era reconhecidamente motivo e objeto de inúmeros poemas, mas nunca o poeta sul-americano havia sido reconhecido como enunciador do universal. A angústia não apenas separa, nesse lugar, o poeta da poesia, mas o sujeito de sua própria subjetividade. Transpor o limiar da angústia no confronto com 
a tradição não é simplesmente decifrar o enigma da esfinge que obstrui a passagem. Na verdade, a esfinge não reconhece a chegada desse viajante e não lhe dirige a palavra.

Em Sol (segunda "dentição", n. 11), Oswald de Andrade alude ao fato de que o sol, o mesmo sol, brilha por toda parte - por todo o Brasil, como pela Espanha, no mediterrâneo e no Egito. Nas antigas civilizações, no velho, e no novo mundo. A observação deixa implícita a ingênua questão: por que esta cultura não poderia, também, reivindicar sua universalidade? Uma reflexão mais detida, entretanto, o conduzirá por outro caminho. Em Meditação no horto (segunda "dentição", n. 12), o poeta observa a variedade e abundância de "nossas florestas", onde se encontram todos os tipos de árvore. Uma, entretanto, falta: a árvore do bem. A árvore originária mítica da tradição ocidental, da civilização cristã. Se não está a árvore originária, do fruto do conhecimento do bem e do mal, seria certamente esforço desperdiçado tentar morder seus frutos.

Todo poeta se apropria criativamente de uma tradição. De uma tradição dentro de sua língua ou uma tradição compartilhada pela tradução e outros trânsitos culturais. Dizer que a apropriação cultural criativa é o sentido e a força do projeto da antropofagia seria, nesse sentido, uma banalidade. Entretanto, como escreve Alfredo Cesar Melo (2016), persiste uma certa retórica antropofágica, ainda vigente em boa parte da crítica cultural brasileira, que sempre renovadamente busca enaltecer as formas como escritores e artistas brasileiros se apropriam, deformam ou subvertem modelos europeus. Como resultado prático, esse discurso pode levar à melhora na autoestima nacional. Ele não chega, no entanto, a exercer qualquer efeito na real assimetria que existe entre as culturas periféricas e centrais. 
O projeto literário da antropofagia propõe estratégias para lidar com a angústia particular de uma influência completamente autocentrada do Ocidente que proscreve todo o diálogo com o Outro. De forma original e bem-humorada, essa estratégia não busca argumentar contra a caracterização de si como Outro antropófago -, mas a celebra, elevando-a à universalidade por seus próprios critérios ("Só a antropofagia nos une"; "Única lei do mundo"), em oposição às particularidades do Ocidente ("sublimações antagônicas [...] trazidas nas Caravelas"). Busca, assim, desconstruir as premissas da autoridade provinciana do Ocidente ("Sem nós a Europa não teria siquer a sua pobre declaração dos direitos do homem [...]"), opondo-se a ela ("Contra Goethe, a mãe dos Gracos, e a corte de D. João VI" - Revista de Antropofagia, Ano 1, n. 1, p. 3). Ao mesmo tempo, a condição racializada que impede o acesso almejado à mesa de jantar e à sala de debates do Ocidente é ficcionalizada por meio de um apagamento dos grupos subalternizados pelo colonialismo interno brasileiro. Os povos indígenas, como figuras emblemáticas do Outro do Ocidente, são confinados a um passado idealizado, negados em suas lutas e territórios contemporâneos. A população negra, por sua vez, é minimizada ao ponto de um quase apagamento, num conluio implícito com a política do embranquecimento que vai assumir a forma ideológica da democracia racial na década seguinte. Já a imigração japonesa recebe um breve comentário de Sylvestre Machado no número oitavo, apenas para ser defendida por sua capacidade de integração e semelhança com o indígena, podendo desaparecer na peculiaridade da miscigenação antropófaga.

De resto, a força da autoestima reencontrada, ao passo que contorna a esfinge eurocêntrica da tradição ocidental, como 
a uma "pedra no meio do caminho", não extingue a angústia da dependência. Permanece vedado o acesso ao "jardim das musas". Repete-se a questão pelas origens e o desafio de fundar uma outra tradição literária. A solução não é a loba romana, nem a anta que abre caminho para seus filhos, tampouco o avestruz - escolhido por Alcântara Machado para representar a primeira fase da revista - que esconde a cabeça na terra a fim de evitar o olhar do Outro que não o reconhece como um outro Eu. Os totens eleitos para a segunda "dentição", opções que permitem a criação deslocada, são o tamanduá, que mete a língua na terra sem medo de ser queimado pelas saúvas, e o jabuti, que aguarda preguiçosamente a hora de sua astuta vingança. Essa solução criativa, por sua vez, não eliminava tampouco a angústia do não reconhecimento. Como levar adiante uma tradição poética gerada desde esse lugar outro, no encontro desses outros povos, produzido pela expansão do Ocidente, e ser reconhecido pela tradição ocidental? Onde Hamlet se debatia entre a angústia de uma existência sem sentido e o sem sentido da libertação pela morte, o poeta antropófago se debatia entre a hesitante, ainda que espalhafatosa, afirmação de sua não ocidentalidade e a angústia de seu não reconhecimento pelo Ocidente: "Tupy or not tupy, that's the question.".

\section{Referências}

ANDERSON, Benedict. Comunidades imaginadas: reflexões sobre a origem e a difusão do nacionalismo. Tradução de Denise Bottman. São Paulo: Companhia das Letras, 2011.

ANDRADE, Oswald de. A utopia antropofágica. São Paulo: Editora Globo, 2011. 
BLOOM, Harold. A angústia da influência: uma teoria da poesia. Tradução de Marcos Santana. 2. ed. Rio de Janeiro: Imago, 2002.

CANDIDO, Antonio. A educação pela noite e outros ensaios. São Paulo: Editora Atica, 1987a.

CANDIDO, Antonio. Literatura de dois gumes. In: A educação pela noite e outros ensaios. São Paulo: Editora Atica, 1987b.

CANDIDO, Antonio. Formação da literatura brasileira: momentos decisivos 1750-1880. Rio de Janeiro: Ouro sobre Azul, 2013.

CANDIDO, Antonio. Literatura e sociedade: estudos de teoria e história literária. Rio de Janeiro: Ouro sobre Azul, 2011.

CARDOSO, Rodrigo Octávio. Colonialidade, transculturação e identidade nacional na antropofagia modernista. Entre Caníbales. Lima, vol. 2, n. 9, 2018.

CARDOSO, Rodrigo Octávio. A questão do primitivismo e a representação dos povos indígenas em Antonio Candido. Revista Criação \& Crítica. São Paulo, n. 26, 2020, p. 55-70.

CARDOSO, Rodrigo Octávio. Políticas do primitivismo na América Latina: raça, nação e utopia em Amauta e na Revista de Antropofagia. Tese (Doutorado em Teoria e História Literária) - UNICAMP, Campinas, 2021. Disponível em http://www. repositorio.unicamp.br/acervo/detalhe/1231115. Acesso em 11 dez. 2021.

CHEAH, Pheng. Spectral Nationality: Passages of Freedom from Kant to Postcolonial Literatures of Liberation. Nova York: Columbia University Press, 2003.

DEL PICCHIA, Menotti. Matemos Peri. Correio Paulistano, São Paulo, 5 jan. 1927.

FERREIRA DA SILVA, Denise. Toward a global idea of race. Minneapolis: University of Minnesota Press, 2007. 
GLISSANT, Édouard. Introdução a uma poética da diversidade. Tradução de Enilce Albergaria Rocha. Juiz de Fora: UFJF, 2005.

GOMES, Heloisa Toller. A Questão Racial na Gestação da Antropofagia Oswaldiana. In: ROCHA, João Cezar de Castro; RUFFINELLI, Jorge (org.). Antropofagia hoje?: Oswald de Andrade em cena. São Paulo: É Realizações, 2011.

HAROOTUNIAN, Harry. 'Modernity' and the claims of untimeliness. Postcolonial Studies, [S. l.], v. 13, n. 4, p. 367$382,2010$.

JÁUREGUI, Carlos. Canibalia: canibalismo, calibanismo, antropofagia cultural y consumo en América Latina. Madrid: Iberoamericana, 2008.

MELO, Alfredo Cesar Barbosa. Antropófagos devorados e seus desencontros: da "formação" à "inserção" da literatura brasileira. Literatura e Sociedade, São Paulo, [s. l.], v. 21, n. 22, p. 42-54, 2016.

MORAES, Eduardo Jardim de. Modernismo revisitado. Revista Estudos Históricos, [s. l.], v. 1, n. 2, p. 220-238, 1988.

NASCIMENTO, Abdias. O genocídio do negro brasileiro: processo de um racismo mascarado. São Paulo: Editora Perspectiva S.A, 2016.

O ATUAL momento literário. Correio Paulistano, São Paulo, 17 maio 1927.

QUEIROZ, Helaine Nolasco. Verdeamarelo/Anta e Antropofagia: narrativas da identidade nacional brasileira. 2010. Dissertação (Mestrado em História) - Universidade Federal de Minas Gerais, Belo Horizonte, 2010. Disponível em: https://repositorio.ufmg.br/bitstream/1843/VCSA-8MJJY6/1/ disserta_o_de_helaine_nolasco_queiroz.pdf. Acesso em: 24 jun. 2020. 
REVISTA DE ANTROPOFAGIA. In: PUNTONI, P; TITAN JR.; S (org.) Revistas do Modernismo - 1922-1929 - Edição Fac-similar. São Paulo: Imprensa Oficial do Estado de São Paulo, Biblioteca Brasiliana Guita e José Mindlin, 2014.

SAKAI, Naoki. O Ocidente - uma prescrição ou proscrição dialógica. Remate de Males, [S. l.], v. 40, n. 1, p. 363-388, 2020. SANTIAGO, Silviano. Uma literatura nos trópicos: ensaios sobre dependência cultural. Rio de Janeiro: Rocco, 2000.

SCHWARZ, Roberto. As ideias fora do lugar. In: SCHWARZ, Roberto. Cultura e política. São Paulo, SP: Paz e Terra, 2009a. SCHWARZ, Roberto. Nacional por subtração. In: SCHWARZ, Roberto. Cultura e política. São Paulo, SP: Paz e Terra, 2009b. STEPAN, Nancy Leys. The Hour of Eugenics: Race, Gender, and Nation in Latin America. Ithaca: Cornell University Press, 2015.

STERZI, Eduardo. Onde a Linha?. Boletim de Pesquisa NELIC, [S. l.], p. 22-27, 2011. 